\title{
OPTIMASI PENEMPATAN DISTRIBUTED GENERATION PADA PENYULANG GOA LAWAH MENGGUNAKAN METODE PARTICLE SWARM OPTIMIZATION (PSO)
}

\author{
I Made Bagas Sastra Negara ${ }^{1}$, Ngakan Putu Satriya Utama ${ }^{2}$, Cok Gede Indra \\ Partha $^{3}$ \\ Program Studi Teknik Elektro, Fakultas Teknik, Universitas Udayana.
}

Email: bagassastra95@gmail.com ${ }^{1}$, ngakansatriya@ee.unud.ac.id ${ }^{2}$, cokindra@unud.ac $\underline{. i d}^{3}$

\begin{abstract}
Abstrak
Distributed Generation (DG) merupakan pembangkit listrik skala kecil yang umumnya berada dekat dengan pusat beban. Penyulang Goa Lawah merupakan penyulang yang berada dekat dengan potensi DG yaitu berupa Pembangkit Listrik Tenaga Mini Hidro (PLTMH) pada sungai Unda yang berada di Kabupaten Klungkung. Dalam penelitian ini dilakukan optimasi penempatan Distributed Generation ke penyulang Goa Lawah. Optimasi penempatan Distributed Generation bertujuan untuk menurunkan nilai rugi-rugi daya yang ada pada penyulang Goa Lawah. Hasil penelitian yang telah dilakukan diperoleh penempatan Distributed Generation pada titik bus 123 menggunakan metode Particle Swarm Optimization (PSO), dengan penurunan rugi-rugi daya sebesar 41 kW (44\%). Rugi-rugi awal sebelum interkoneksi DG sebesar 72 kW setelah interkoneksi Distributed Generation menjadi 31 kW.
\end{abstract}

Kata Kunci : Load Flow Analysis, Rugi-Rugi Daya, Particle Swarm Optimization

\begin{abstract}
Distributed Generation (DG) is a small-scale power plant located close to the center of load. Goa Lawah feeder is a broadcast that is close to the potential of DG namely the Mini Hydro Power Plant on the Unda River in Klungkung Regency. In this research the optimization of Distributed Generation placement to Goa Lawah feeder. Optimization of Distributed Generation placement aims to reduce the value of loss of power that exist in the feeder Goa Lawah. The results of the research obtained at the point of bus 123 by Distributed Generation placement using Particle Swarm Optimization (PSO) method, with power loss $41 \mathrm{~kW}(44 \%)$. The initial loss before the Distributed Generation interconnection of $72 \mathrm{~kW}$ after the Distributed Generation interconnection to $31 \mathrm{~kW}$.
\end{abstract}

Keywords : Load Flow Analyzes, Power Loss, Particle Swarm Optimization

\section{PENDAHULUAN}

Energi listrik merupakan energi yang sangat bermanfaat bagi kehidupan manusia. Laju pertumbuhan ekonomi dan pertambahan penduduk merupakan penyebab masalah penyediaan energi listrik di masa datang. Sumber energi terbarukan memilki potensi yang sangat besar untuk dikembangkan, maka dari itu perlu adanya pemanfaatan sistem energi terbarukan. Salah satu pembangkit listrik yang menggunakan energi terbarukan adalah Distributed Generation.

Pembangkit listrik tersebar dengan kapasitas kecil disebut dengan Distributed Generation (DG) yang biasanya terletak dekat dengan beban pada sistem distribusi tenaga listrik [1]. Salah satu cara untuk menurunkan rugi-rugi daya pada jaringan distribusi tenaga listrik yaitu dengan 
memasang DG di lokasi yang tepat pada sistem distribusi tenaga listrik [2].

Pembangkit Listrik Tenaga Mini Hidro (PLTMH) adalah pembangkit listrik dengan kapasitas kecil. Di Bali potensi untuk dibangun PLTMH cukup banyak salah satunya yaitu sungai atau bendungan Tukad Unda. Data Bappenas tahun 2016 menyatakan potensi pembangkit listrik pada Tukad Unda sebesar 1,2 MW [3]. Penyulang yang berada paling dekat dengan Tukad Unda yaitu Penyulang Goa Lawah.

Penyulang Goa Lawah merupakan JTM yang di suplay dari Gardu Induk Gianyar, dengan kapasitas daya 60 MVA. Penyulang Goa Lawah memiliki panjang jaringan sekitar $64 \mathrm{kms}$, dan melayani 69 trafo distribusi.

Metode optimasi digunakan untuk mencari solusi dari suatu permasalahan seperti, PSO diterapkan pada jaringan ad hoc nirkabel dalam pemilihan pasangan lintasan [4]. Optimasi menggunakan Genetic Algorithm (GA) untuk menentukan Rute pasangan lintasan yang optimal melalui multi-kriteria pada jaringan ad hoc [5].

Pada penelitian ini, dilakukan optimasi penempatan Distributed Generation pada Penyulang Goa Lawah untuk menurunkan rugi-rugi daya aktif menggunakan metode Particle Swarm Optimization.

\section{KAJIAN PUSTAKA}

\subsection{Sistem Distribusi}

Sistem distribusi tenaga listrik merupakan sub sistem tenaga listrik yang berfungsi untuk menyalurkan atau mendistribusikan energi listrik dari sumber energi sampai ke konsumen. Jadi sistem distribusi ini merupakan sub sistem yang berhubungan langsung dengan pelanggan karena sistem distribusi secara langsung melayani pusat-pusat beban. Jaringan distribusi primer dan jaringan distribusi sekunder merupakan bagian dari sistem jaringan distribusi. Jaringan distribusi primer umumnya mempunyai nilai tegangan sebesar $20 \mathrm{kV}$. Tegangan $20 \mathrm{kV}$ tersebut kemudian diturunkan menggunakan transformator distribusi menjadi tegangan rendah (220V atau 380V) untuk selanjutnya disalurkan ke beban atau pelanggan melalui saluran distribusi sekunder [6]. Jadi jaringan distribusi dibagi menjadi 2 yaitu sebagai berikut :

a. Distribusi Primer, sering disebut Jaringan Tegangan Menengah (JTM) tersusun dari penyulang utama (main feeder) dan penyulang percabangan (lateral). Sistem penyaluran daya listrik pada sistem jaringan distribusi primer dapat dibedakan menjadi tiga yaitu, Saluran Kabel Udara Tegangan Menengah (SKUTM), Saluran Udara Tegangan Menengah (SUTM), Saluran Kabel Tegangan Menengah (SKTM).

b. Distribusi Sekunder, atau biasa dikenal dengan Jaringan Tegangan Rendah (JTR) merupakan jaringan yang mempunyai fungsi sebagai penyalur tenaga listrik dari gardu distribusi ke konsumen tenaga listrik. Besarnya standar tegangan untuk jaringan distribusi sekunder di Indonesia adalah $220 \mathrm{~V}$ atau $380 \mathrm{~V}$. Sistem penyaluran daya listrik pada jaringan distribusi sekunder dapat dibedakan menyadi dua yaitu, Saluran Udara Tegangan Rendah (SUTR) dan Saluran Kabel Udara Tegangan Rendah (SKUTR).

\subsection{Distributed Generation}

Pembangkit tenaga listrik yang memiliki kapasitas dengan ukuran yang kecil biasa disebut dengan Distributed Generation (DG) yang berfungsi untuk menyalurkan energi listrik dekat dengan konsumen atau pusat beban, dimana Distributed Generation biasanya akan terhubung dengan sistem distribusi, pelanggan atau pusat beban. Yang tergolong kedalam DG yaitu fuel cells, microturbine, panel photovoltaic, internal combustion engine. DG juga digunakan untuk mensuplai beban puncak, beban dasar, dapat juga sebagai stabilitas jaringan, menaikkan tegangan dan yang pada akhirnya memberikan 
manfaat ekonomi lebih dari energi yang sederhana [7]. Distributed generation mempunyai dampak yang sangat berpengaruh dengan rugi-rugi daya yang ditempatkan dekat dengan pusat beban. Jaringan distribusi yang memiliki tingkat rugi daya yang tinggi sebaiknya ditempatkan Unit Distributed Generation. Bali sedang mempertimbangkan sumber daya energi terbarukan seperti hidro, panas bumi, matahari, angin, dan biomassa sebagai alternatif untuk kebutuhan energi masa depan. Karena sebagian besar biaya investasi awal DG memiliki resiko investasi dibandingkan dengan perencanaan perluasan yang lebih rendah, karena itu menjadi tantangan untuk mengintegrasikan DG ke dalam jaringan distribusi tenaga listrik. Instalasi DG yang kurang baik seperti lokasi atau penempatan dan kapasitas DG dapat menyebabkan kerugian seperti peningkatan rugi-rugi daya, merusak tegangan, proteksi, harmonik, dan stabilitas [8].

\subsection{Perhitungan Rugi-Rugi Daya}

Daya yang hilang dalam penyaluran daya listrik disebut dengan rugi-rugi daya yang diakibatkan oleh faktor-faktor tertentu seperti penampang saluran, beban, dan jarak saluran listrik ke pelanggan yang terlalu jauh, menyebabkan bertambah besarnya tahanan saluran kabel yang digunakan [9]. Adapun persamaan rugirugi daya sebagai berikut :

$$
\Delta \mathrm{P}=I^{2} R
$$

Dengan,

$\Delta \mathrm{P}$ adalah Rugi-rugi daya (W)

$I$ adalah Arus (A)

R adalah Hambatan penghantar $(\Omega)$

\subsection{Konversi Satuan Per Unit}

Berdasarkan data yang diperoleh nilai $\mathrm{R}$ dan $\mathrm{X}$ masih belum dalam satuan per unit (p.u), sedangkan data yang dimasukkan ke dalam listing program nilai $\mathrm{R}$ dan $\mathrm{X}$ harus dalam bentuk satuan p.u. Maka dari itu, perlu dilakukan penyederhanaan untuk nilai
$\mathrm{R}$ dan $\mathrm{X}$ menggunakan persamaan 2 yang dapat dilihat dibawah ini [10].

Base impedance $(Z): \frac{(K V \text { Dasar })^{2}}{\text { MVA Dasar } 3 \varnothing}$

Nilai $\mathrm{R}$ dan $\mathrm{X}$ dalam p.u digunakan sebagai data inputan dalam listing program untuk mencari nilai rugi-rugi daya dan lokasi interkoneksi DG pada Penyulang Goa Lawah menggunakan metode Particle Swarm Optimization.

\subsection{Metode Particle Swarm Optimization (PSO)}

Particle Sarm Optimization merupakan sebuah metode optimasi yang berdasarkan pada swarm intelligence atau disebut algoritma behaviorally inspired yang dapat digunakan sebagai alternatif dari algoritma genetika. Dalam optimasi multivariable seperti PSO, kawanan dianggap memiliki ukuran tertentu dan posisi yang acak untuk setiap partikel dalam ruang multidimensi. Setiap partikel pada PSO dianggap memiliki 2 karakter, yaitu : posisi dan kecepatan. Masing-masing partikel akan mengingat posisi terbaik yang sudah dilalui sebelumnya [11].

Berikut ini adalah langkah-langkah dari program Particle Swarm Optimization (PSO):

1. Menentukan ukuran swarm, dan kecepatan partikel secara acak

2. Evaluasi nilai fungsi tujuan pada setiap partikel.

3. Menentukan nilai Pbest dan Gbest awal.

4. Persamaan untuk menghitung kecepatan pada iterasi selanjutnya dengan menggunakan berikut [12]:

$$
\begin{aligned}
& V_{i}(t)=V_{i}(t-1)+c_{1} r_{1}\left(X_{i}^{L}-\right. \\
& \left.X_{i}(t-1)\right)+c_{2} r_{2}\left(X^{G}-X_{i}(t-1)\right) \\
& \ldots \ldots \ldots \ldots . . .(3) \\
& \text { Dimana : } \\
& \mathrm{t}=\text { iterasi ke-t } \\
& \mathrm{i}=\text { indeks partikel } \\
& r_{1} \text { dan } r_{2}=\text { bilangan acak }
\end{aligned}
$$

5. Persamaan untuk menentukan posisi partikel pada iterasi selanjutnya : 
$X_{i}(t)=V_{i}(t)+X_{i}(t-1)$

Dimana :

$X_{i}=$ posisi partikel

$V_{i}=$ kecepatan partikel

6. Melakukan evaluasi nilai fungsi tujuan pada iterasi berikutnya.

7. Memperbaharui nilai Pbest dan Gbest.

8. Melakukan pengecekan apakah solusi sudah optimal atau belum. Jika sudah mendapatkan hasil yang optimal, maka proses algoritma akan berhenti, tetapi jika hasil yang didapat belum optimal maka proses akan diulangi kembali pada langkah nomor 4.

\section{METODE PENELITIAN}

\subsection{Alur Program PSO}

Alur Program PSO yang digunakan dapat dilihat pada Gambar 1 [10]:

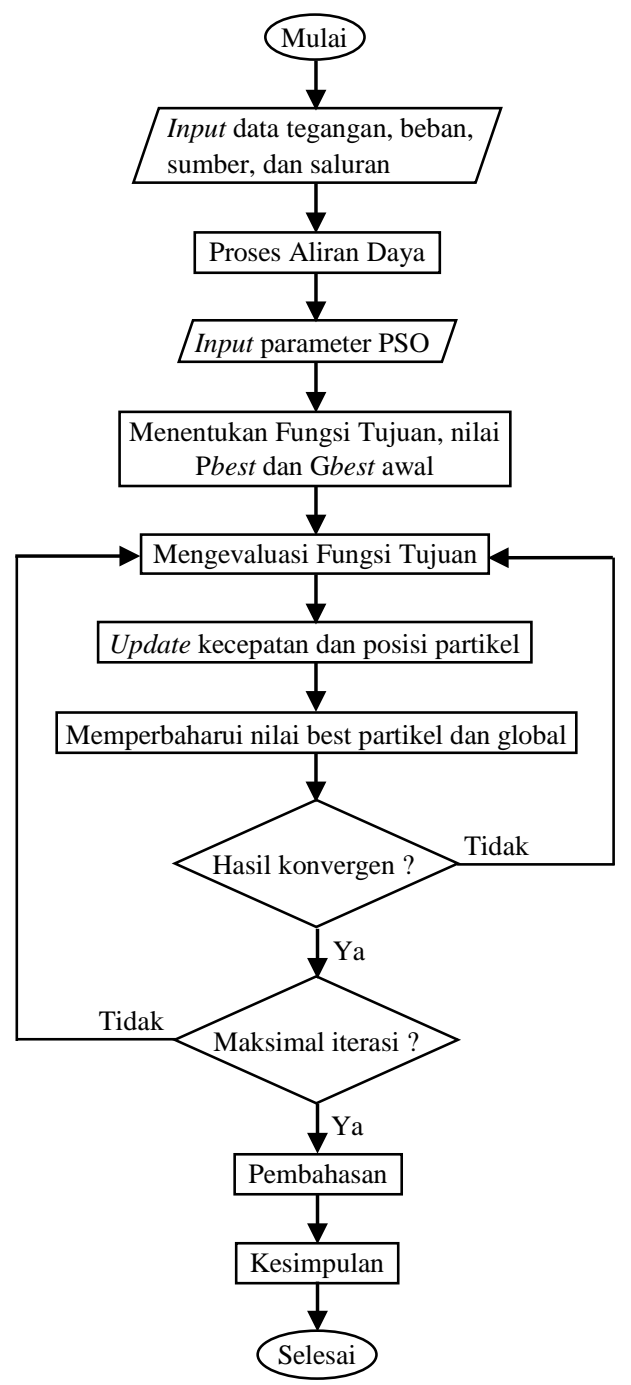

Gambar 1. Diagram Alur Program PSO

Penelitian ini dilakukan dalam beberapa tahapan sebagai berikut :

1. Pengumpulan data-data Penyulang Goa Lawah.

2. Menghitung besar rugi-rugi awal pada Penyulang Goa Lawah.

3. Menginput parameter PSO.

4. Mengevaluasi Fungsi Tujuan.

5. Memperbaharui nilai kecepatan dan posisi setiap partikel dengan menggunakan persamaan (3) dan (4)

6. Mendapatkan lokasi interkoneksi DG.

7. Menghitung rugi-rugi daya setelah melakukan interkoneksi DG.

8. Analisis hasil rugi-rugi daya sebelum dan sesudah interkoneksi DG

\section{HASIL DAN PEMBAHASAN}

\subsection{Gambaran Umum Penyulang Goa Lawah}

Penyulang Goa Lawah merupakan Jaringan Tegangan Menengah (JTM) yang disuplay dari trafo I Gardu Induk Gianyar, dengan kapasitas 60 MVA. Penyulang Goa Lawah memiliki panjang saluran mencapai $64 \mathrm{~km}$ dan mengoperasikan 69 unit trafo distribusi yang tersebar di daerah Klungkung kota dan sekitarnya. Penyulang Goa Lawah merupakan salah satu penyulang yang berada pada wilayah kerja PT. PLN (Persero) Rayon Klungkung yang berfungsi untuk menyalurkan tenaga listrik ke konsumen di daerah Klungkung dan sekitarnya. Sistem topologi yang dipergunakan pada Penyulang Goa Lawah adalah topologi tipe loop, namun dalam pengoperasian menggunakan sistem radial. Jenis penghantar yang digunakan berbedabeda sesuai dengan jenis tegangan menengah saluran masing-masing yaitu : AAAC dan AAACs untuk SUTM, MVTIC untuk SKUTM, dan NA2XSEBY untuk SKTM dimana keseluruhannya bekerja pada tegangan $20 \mathrm{kV}$. Penghantar AAAC, AAACs dan MVTIC menggunakan diameter $150 \mathrm{~mm}^{2}$, sedangkan untuk kabel tanah menggunakan penghantar berdiameter 240 
$m m^{2}$. Setiap ujung jaringan Penyulang Goa Lawah terkoneksi dengan penyulang lain yang berdekatan pada Penyulang Goa Lawah, yang dipisahkan oleh sebuah Load Break Switch (LBS) yang dalam pengoperasiannya dalam kondisi terbuka (normally open).

\subsection{Perhitungan Rugi Daya Awal Sebelum Interkoneksi DG}

Perhitungan rugi daya dilakukan untuk mengetahui berapa besar rugi-rugi daya yang terdapat pada penyulang Goa Lawah. Data yang diperlukan dalam perhitungan rugi-rugi daya berupa nomor bus, volt (mag), angle (deg), load, generator dan impedansi (p.u).

Tabel 1. Data Bus Penyulang Goa Lawah

\begin{tabular}{|c|c|c|c|c|c|c|}
\hline Bus & Volt & Ang. & \multicolumn{2}{|c|}{ Load } & \multicolumn{2}{c|}{ Generator } \\
\cline { 4 - 7 } no. & mag & deg & MW & MVAR & MW & MVAR \\
\hline 1 & 1.0000 & 0.0 & 0 & 0 & 2.820 & 1.729 \\
\hline 2 & 1.0000 & 0.0 & 0 & 0 & 0 & 0 \\
\hline 3 & 1.0000 & 0.0 & 0 & 0 & 0 & 0 \\
\hline 4 & 1.0000 & 0.0 & 0 & 0 & 0 & 0 \\
\hline 5 & 1.0000 & 0.0 & 0 & 0 & 0 & 0 \\
\hline$\ldots$ & $\ldots$ & $\ldots$ & $\ldots$ & $\ldots$ & $\ldots$ & $\ldots$ \\
\hline 200 & 1.0000 & 0.0 & 0.017 & 0.011 & 0 & 0 \\
\hline
\end{tabular}

Tabel 2. Data Saluran Penyulang Goa Lawah

\begin{tabular}{|c|c|c|c|}
\hline $\begin{array}{c}\text { From } \\
\text { bus }\end{array}$ & $\begin{array}{c}\text { To } \\
\text { bus }\end{array}$ & $\mathrm{R}(\mathrm{p} . \mathrm{u})$ & $\mathrm{X}(\mathrm{p} . \mathrm{u})$ \\
\hline $\begin{array}{c}\text { Bus } \\
\text { 001 }\end{array}$ & $\begin{array}{c}\text { Bus } \\
002\end{array}$ & 0.00000025 & 0.00000025 \\
\hline $\begin{array}{c}\text { Bus } \\
002\end{array}$ & $\begin{array}{c}\text { Bus } \\
003\end{array}$ & 0.001251906 & 0.042689975 \\
\hline $\begin{array}{c}\text { Bus } \\
003\end{array}$ & $\begin{array}{c}\text { Bus } \\
004\end{array}$ & 0.000238146 & 0.000289688 \\
\hline $\begin{array}{c}\text { Bus } \\
\text { 004 }\end{array}$ & $\begin{array}{c}\text { Bus } \\
\text { 005 }\end{array}$ & 0.04855565 & 0.06441165 \\
\hline $\begin{array}{c}\text { Bus } \\
\text { 005 }\end{array}$ & $\begin{array}{c}\text { Bus } \\
006\end{array}$ & 0.0103674 & 0.013752913 \\
\hline$\cdots$ & $\ldots$ & $\ldots$ & $\ldots$ \\
\hline $\begin{array}{c}\text { Bus } \\
199\end{array}$ & $\begin{array}{c}\text { Bus } \\
200\end{array}$ & 3.752695 & 9.269158 \\
\hline
\end{tabular}

Data dari Tabel 1 dan Tabel 2 merupakan data hasil perhitungan, yang sebelumnya perlu dilakukan perubahan bentuk supaya dapat dibaca oleh listing program load flow, seperti pemberian kode bus pada data dan penentuan MVA Base yang akan digunakan. Penentuan MVA Base berguna untuk mempermudah perhitungan losses, sehingga untuk MVA Base pada penelitian ini menggunakan 100 MVA. Kode bus yang akan digunakan adalah dengan kode 0,1 , dan 2 . Kode bus 0 merupakan kode bus untuk bus beban, dimana dari bus beban parameter yang diketahui berupa beban $\mathrm{P}$ dan Q. Kode bus 1 merupakan kode bus untuk slack bus, untuk slack bus parameter utama yang diketahui berupa tegangan sudut dan tegangan. Kode bus 2 merupakan kode bus untuk pv bus, dimana dari pv bus parameter yang diketahui berupa tegangan, daya $\mathrm{P}$ dari generator.

Perhitungan load flow dilakukan untuk mengetahui berapa rugi-rugi daya yang ada pada saluran Penyulang Goa Lawah sebelum interkoneksi DG. Dimana perhitungan load flow tersebut memperoleh hasil seperti pada Tabel 3.

Tabel 3. Rugi-rugi daya pada Penyulang Goa Lawah sebelum Interkoneksi DG

\begin{tabular}{|c|c|c|c|}
\hline No & Uraian & Nilai & Keterangan \\
\hline 1 & Total daya & $2819 \mathrm{~kW}$ & Gl Gianyar \\
\hline 2 & Rugi daya & $72 \mathrm{~kW}$ & $2,56 \%$ dari total daya \\
\hline
\end{tabular}

Hasil perhitungan load flow bisa dilihat pada Tabel 3. Hasil rugi-rugi daya pada jaringan distribusi Penyulang Goa Lawah sebelum interkoneksi Distributed Generation yaitu sebesar $72 \mathrm{~kW}$ atau $2,56 \%$ dari total daya.

\subsection{Penentuan Titik Interkoneksi DG}

Perhitungan rugi-rugi daya awal pada Penyulang Goa Lawah akan dibaca atau sebagai input untuk menentukan lokasi titik interkoneksi DG dengan menggunakan metode Particle Swarm Optimization (PSO). Listing program akan mencari lokasi untuk inject DG yang memperoleh rugi-rugi daya aktif terendah. Fitness function yang dipergunakan dalam penelitian ini adalah sebagai berikut:

$f=\sum_{i=1}^{n} \sum_{j=1}^{n}\left(\alpha_{i j}\left(P_{i} P_{j}+Q_{i} Q_{j}\right)+\beta_{i j}\left(Q_{i} P_{j}+Q_{i} P_{j}\right)\right)$ 
Dengan,

$\alpha_{i j}=\frac{R_{i j}}{\left|v_{i}\right|\left|v_{j}\right|} \cos \left(\delta_{i}-\delta_{j}\right)$

$\beta_{i j}=\frac{R_{i j}}{\left|v_{i}\right|\left|v_{j}\right|} \sin \left(\delta_{i}-\delta_{j}\right)$

$P_{i}$ dan $P_{j}$ adalah daya aktif bus $\mathrm{i}$ dan $\mathrm{j}$

$Q_{i}$ dan $Q_{j}$ adalah daya reaktif bus i dan j

$V_{i}$ dan $V_{j}$ adalah tegangan bus i dan j

$\delta_{i}$ dan $\delta_{j}$ adalah sudut bus i dan j

$R_{i j}$ adalah sudut bus i dan j

Dari pemetaan fitness function yang dilakukan, fungsi tujuan yang akan dicapai sebagai berikut :

Dengan batasan :

$$
P_{L}=\sum_{k=1}^{n} \operatorname{Loss}_{k}
$$

Batasan tegangan : $|V i|^{\text {min }} \leq|V i| \leq|V i|^{\text {max }}$ Dengan,

$P_{L}$ adalah rugi-rugi daya nyata pada sistem $\operatorname{Loss}_{k}$ adalah rugi-rugi tegangan pada titik k

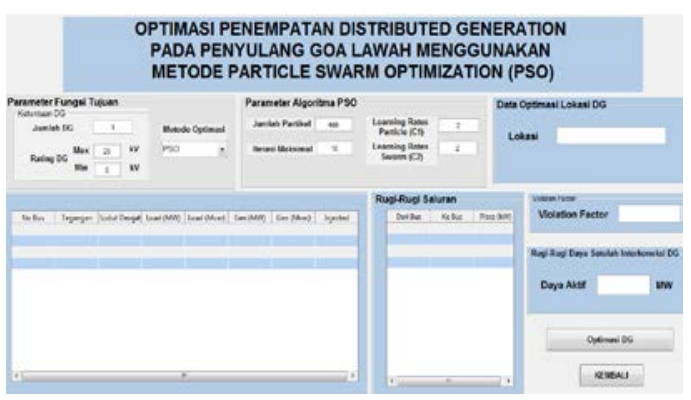

Gambar 2. Optimasi interkoneksi DG

Parameter PSO yang akan digunakan yaitu jumlah partikel, maksimal iterasi, learning rate particle $\left(\mathrm{c}_{1}\right)$, dan learning rate swarm $\left(\mathrm{C}_{2}\right)$. Setelah semua parameter Particle Swarm Optimization (PSO) diisi dengan menekan tombol "optimasi" akan keluar grafik berupa penentuan lokasi titik interkoneksi DG seperti yang diperlihatkan pada Gambar 2.

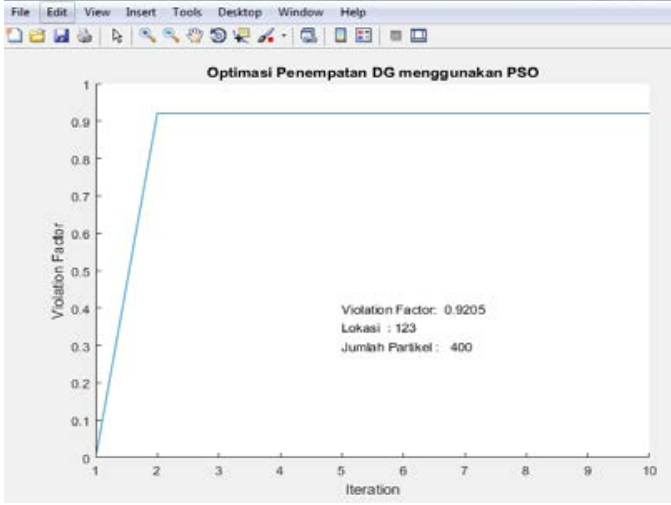

Gambar 3. Grafik lokasi titik Interkoneksi DG

Grafik lokasi titik interkoneksi DG seperti yang ditampilkan pada Gambar 3, diperoleh hasil titik untuk interkoneksi DG pada Penyulang Goa Lawah terdapat pada bus 123 .

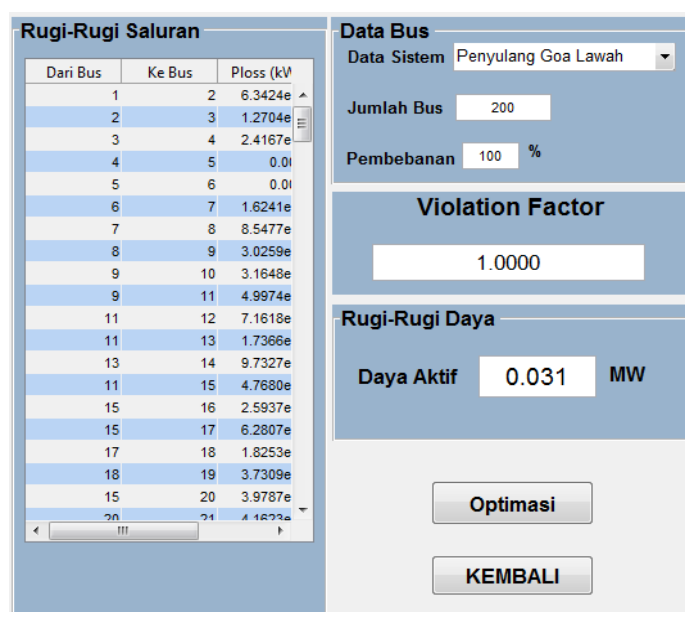

Gambar 4. Hasil rugi daya setelah Interkoneksi DG

Hasil titik untuk interkoneksi Distributed Generation (DG) pada Penyulang Goa Lawah terdapat pada bus 123 . Selanjutnya setelah memperoleh titik untuk interkoneksi DG, maka akan dilakukan interkoneksi DG pada bus 123. Hasil rugi-rugi daya setelah interkoneksi DG pada bus 123 adalah 31 kW, dapat dilihat pada Gambar 4.

Tabel 4. Selisih rugi-rugi daya setelah interkoneksi DG

\begin{tabular}{|l|lr|l|}
\hline No & Uraian sebelum & Nilai \\
\hline 1 & $\begin{array}{l}\text { Rugi daya } \\
\text { Interkoneksi DG } \\
\text { kW }\end{array}$ \\
\hline 2 & $\begin{array}{l}\text { Rugi daya setelah } \\
\text { Interkoneksi DG }\end{array}$ & $\begin{array}{l}31 \\
\mathrm{~kW}\end{array}$ \\
\hline \multicolumn{2}{|l|}{ Selisih rugi-rugi daya } & $\begin{array}{l}41 \\
\mathrm{~kW}\end{array}$ \\
\hline
\end{tabular}


Selisih rugi-rugi daya yang ada sebelum dan sesudah interkoneksi DG adalah sebesar $41 \mathrm{~kW}$ atau $44 \%$, seperti yang ada pada Tabel 4 .

\section{KESIMPULAN}

Berdasarkan hasil analisis dan pembahasan yang telah dilakukan dalam penelitian ini, diperoleh kesimpulan :

1. Lokasi titik interkoneksi DG pada Penyulang Goa Lawah menggunakan metode Particle Swarm Optimization (PSO) pada lokasi bus 123.

2. Setelah dilakukan optimasi penempatan DG dengan titik lokasi bus 123 didapatkan rugi-rugi daya pada Penyulang Goa Lawah menurun menjadi $31 \mathrm{~kW}$ dengan rugi-rugi awal dari Penyulang Goa Lawah sebesar 72 kW. Terjadi penurunan rugi-rugi daya sebesar $41 \mathrm{~kW}$ (44\%).

\section{DAFTAR PUSTAKA}

[1] N. P. Satriya Utama, R. S. Hartati, W. G. Ariastina, dan I. B. A. Swamardika, "A Placement and Sizing of Distributed Generation Based on Combines Sensitivity Factor and Particle Swarm Optimization: A Case Study in Bali's Power Transmission Networks," Int. J. Eng. Emerg. Technol., vol. 2, no. 2, hlm. 20, Des 2017.

[2] E. P. Santosa, O. Penangsang, N. K. Aryani, dan J. A. R. Hakim, "Optimasi Penentuan Lokasi Kapasitor dan Distributed Generation (DG) Dengan Rekonfigurasi Jaringan Untuk Meningkatkan Keluaran Daya Aktif DG Pada Sistem Distribusi Radial Menggunakan Genetic Algorithm (GA)," J. Tek. ITS, vol. 5, no. 2, 2016.

[3] S. A. Djalil, Konsistensi Nawa Cita Dalam Prioritas Nasional Rencana Kerja Pembangunan Tahun 2017 Terhadap Pembangunan Wilayah Kalimantan. Jakarta: Kementerian Perencanaan Pembangunan Nasional, 2016.

[4] N. Gunantara, P. K. Sudiarta, dan I. N. Gde Antara, "Multi-Criteria Weights on Ad Hoc Networks Using Particle
Swarm Optimization for Optimal Path Pairs," Int. Rev. Electr. Eng., vol. 13, no. 1, 2018.

[5] N. Gunantara dan A. Dharma, "Optimal Path Pair Routes through Multi-Criteria Weights in Ad Hoc Network Using Genetic Algorithm," Int. J. Commun. Netw. Inf. Secur., vol. 9, no. 1, hlm. 88, Apr 2017.

[6] C. Rochman, O. Penangsang, dan N. K. Aryani, "Manajemen Gangguan Jaringan Distribusi 20 kV Kota Surabaya berbasis Geographic Information System (GIS) menggunakan Metode Algoritma Genetika," J. Tek. ITS, vol. 4, no. 1, Mar 2017.

[7] T. Ackermann, "Distributed generation: a definition," Electr. Power Syst. Res., hlm. 195, Des 2000.

[8] N. P. Satriya Utama, R. S. Hartati, W. G. Ariastina, I. B. A. Swamardika, dan O. Penangsang, "A Review on Model of Integrating Renewable Distributed Generation into Bali's Power Distribution Systems: Issues, Challenges, and Possible Solutions," Indones. J. Electr. Eng. Comput. Sci., vol. 4, no. 2, hlm. 245, Nov 2016.

[9] A. Tanjung, "Rekonfigurasi Sistem Distribusi 20 kV Gardu Induk Teluk Lembu Dan Pltmg Langgam Power Untuk Mengurangi Rugi Daya Dan Drop Tegangan," J. Sains Teknol. Dan Ind., vol. 11, no. 2, hlm. 160, Jun 2014.

[10] R. F. Margeritha, R. S. Hartati, dan N. P. Satriya Utama, "Analisis Penyambungan Distributed Generation Guna Meminimalkan Rugi-Rugi Daya Menggunakan Metode Particle Swarm Optimization (PSO)," Maj. IIm. Teknol. Elektro, vol. 16, no. 3, hlm. 122, Des 2017.

[11] Alrijadjis dan K. Astrowulan, "Optimasi Kontroler PID Berbasis Particle Swarm Optimization (PSO) untuk Sistem dengan Waktu Tunda," J. Politek. Elektron. Negeri Surabaya, hlm. 4, 2010.

[12] I. P. S. Handika, I. A. Giriantari, dan A. Dharma, "Perbandingan Metode Extreme Learning Machine dan Particle Swarm Optimization Extreme Learning Machine untuk Peramalan Jumlah Penjualan Barang," Maj. IIm. Teknol. Elektro, vol. 15, no. 1, hlm. 84, Jun 2016. 